\title{
BIOLOGICAL CONTROL: ISOLATED AND IN MIXTURES AND GENETIC CONTROL OF Meloidogyne exigua IN COFFEE
}

\author{
Alex Lavado Tolardo ${ }^{1}$, Gleina Costa Silva Alves², Gustavo Ferreira da Silva ${ }^{3}$, \\ Wellington José Pereira ${ }^{4}$, Débora Zacarias da Silva ${ }^{5}$, Samuel Afonso Sampaio Silva ${ }^{6}$
}

(Received: February 28, 2019; accepted: May 14, 2019)

\begin{abstract}
Meloidogyne exigua is one of the most found species of nematodes in coffee plantations in the Brazilian Cerrado. Thus, the objective of the present study was to evaluate the efficiency of biological agents on two coffee cultivars. The experiment was carried out in a greenhouse using a completely randomized design. The treatments were arranged in a $2 \times 3$ factorial scheme, using repeated measures (two cultivars, 3 nematicides, and 2 additional controls), and were composed of two genotypes (Mundo Novo IAC 376-4 and IPR-100), three biological nematicides (B. methylotrophicus, B. subitilis, and T. asperellum), and two treatments including the three nematicides together, totaling 8 treatments and 2 controls, with 6 replicates each. The plants were inoculated with 3,780 eggs and J2s of the respective nematode. Throughout 150 days, the following variables were evaluated monthly: plant height, stem diameter, number of leaf pairs, and chlorophyll contents. At the end of this period (DAI), the reproductive factor $(\mathrm{RF})$, egg mass and gall index were analyzed. About FR, the results were lower $(<1)$ when using the cultivar IPR-100 when compared to the Mundo Novo genotype, denoting adequate genetic control. On the other hand, in the treatments with the susceptible genotype, high FRs were verified, ranging from 2.64 to 5.68 in the control. It was concluded that the bacterial mixtures were efficient in the control, and B. methylotrophicus contributed to higher plant height in the IPR 100 genotype.
\end{abstract}

Terms for indexation: Root-Knot nematode, Coffea arabica, bacteria, fungi, reproductive factor.

\section{CONTROLE BIOLÓGICO: ISOLADO E EM MISTURAS E CONTROLE GENÉTICO DE Meloidogyne exigua EM CAFÉ}

\begin{abstract}
RESUMO: Meloidogyne exigua é uma das espécies de nematóides mais encontradas em cafezais no Cerrado brasileiro. Assim, o objetivo do presente estudo foi avaliar a eficiência de agentes biológicos em duas cultivares de café. O experimento foi conduzido em casa de vegetação, em delineamento inteiramente casualizado. Os tratamentos foram dispostos em esquema fatorial 2x3, utilizando medidas repetidas (duas cultivares, 3 nematicidas e 2 controles adicionais), sendo compostos por dois genótipos (Mundo Novo IAC 376-4 e IPR-100), três nematicidas biológicos (B. Methylotrophicus, B. subitilis e T. asperellum), e dois tratamentos incluindo os três nematicidas juntos, totalizando 8 tratamentos e 2 testemunhas, com 6 repetições cada. As plantas foram inoculadas com 3.780 ovos e J2s do respectivo nematóide. Ao longo de 150 dias, as seguintes variáveis foram avaliadas mensalmente: altura da planta, diâmetro do caule, número de pares de folhas e teores de clorofila. No final deste período (DAI), o fator reprodutivo (RF), massa de ovos e índice de galhas foram analisados. Em relação à FR, os resultados foram menores $(<1)$ quando da utilização da cultivar IPR-100 quando comparada ao genótipo Mundo Novo, denotando controle genético adequado. Por outro lado, nos tratamentos com o genótipo suscetível, verificaram-se FR altos, variando de 2,64 a 5,68 no controle. Conclui-se que as misturas de biológicos foram eficientes no controle, e B. methylotrophicus contribuiu para maior altura de planta no genótipo IPR 100.
\end{abstract}

Termos para indexação: Nematóide das galhas, Coffea arábica, bactérias, fungos, fator de reprodução.

\section{INTRODUCTION}

Brazil occupies the first place in the world ranking of coffee production and the second as the largest consumer. According to the Companhia Nacional de Abastecimento - CONAB, the estimate for the output of the coffee harvest in 2018 indicates that the country should harvest 58.04 million bags of benefited coffee. Such a result represents an increase of $29.1 \%$ when compared to the production of 44.97 million bags obtained in the last harvest (CONAB, 2018). The coffee crop in the Brazilian agribusiness occupies the fifth position in the export ranking, participating in approximately $5.4 \%$ of the exchange revenue, evidencing its socioeconomic importance (FERREIRA; EMBRAPA, 2018), generating income and jobs in the country.

Among the species of nematodes, those that most seriously damage coffee production in Brazil are the gall nematodes: Meloidogyne exigua, Meloidogyne coffeicola, Meloidogyne incognita, and Meloidogyne paranaensis; due to the intensity of attacks and significant aggressiveness, causing extensive plant damage and losses in productivity (OLIVEIRA et al., 2011). The species

1,2,3,4,5,6Instituto Federal Goiano - Campus Urutaí - Rodovia Prof. Geraldo Silva Nascimento - Km 2,5 - Zona Rural - 75.790-000 Urutaí -GO - alextolardo@gmail.com, gleina.alves@ifgoiano.edu.br, gustavof08@outlook.com, wellingtonjpereira74@gmail.com, debora_zak@hotmail.com, afonsosamuelss@gmail.com 
Meloidogyne exigua deserves distinction due to its wide geographic distribution in Brazil, where it is disseminated in coffee plantations in the major producing regions, primarily the state of Minas Gerais (GONÇALVES et al., 2004).

The main biological control agents of nematodes are fungi and bacteria (ARAÚJO, 2009). In order to reduce the use of pesticides in coffee plantations, studies aimed at the development and use of biological nematode control in coffee crops have been conducted (STIRLING, 2014).

In studies developed with the use of rhizosphere microorganisms, known as rhizobacteria, these organisms provided a defense against the attack of phytonematodes (ARAÚJO, 2015). Another benefit regarding the use of rhizobacteria is the promotion of plant growth, which is the reason why they are also known as PGPR (Plant Growth Promoting Rhizobacteria), contributing to plant development. (BHATTACHARYYA; JHA, 2012)

Examples of PGPR include Bacillus subtilis and Bacillus methylotrophicus. In agricultural crops of great importance, such as tomatoes and carrots, strains of Bacillus subtilis were found to be antagonists of species of Meloidogyne (LINFORD et al., 1938). Bacillus methylotrophicus was also effective in the reduction of nematodes in greenhouse and in vitro trials (ZHOU et al., 2016).

Thus, biological control, coupled with suitable agronomic characteristics of cultivars less susceptible to these nematodes, presents a number of advantages for the crop, since it comprises a cheap management method, easy to apply, does not contaminate, and leaves no residues in the environment, having sustainability of coffee production systems (CARDOSO; ARAÚJO, 2011).

The objective of the present study was to compare the performance of biological products and mixtures compared to the genetic control of Meloidogyne exigua in arabica coffee.

\section{MATERIAL AND METHODS}

The experiment began in September 2017, in the municipality of Urutaí - GO, at the Instituto Federal Goiano - Campus Urutaí, in a greenhouse equipped with a controlled sprinkler irrigation system. The study area was located at the following coordinates: latitude $17^{\circ} 29^{\prime} 3.20^{\prime \prime} \mathrm{S}$, longitude $48^{\circ} 12^{\prime} 46.90^{\prime \prime} \mathrm{W}$, and at an altitude of $723 \mathrm{~m}$.
The experimental design was completely randomized in a time-repeated measures factorial scheme $(2 \times 4+2)$, using two coffee cultivars: IAPAR Mundo Novo 376-4, a taller variety presenting aspects of susceptibility to all the gall nematodes that affect coffee crops, and IPR-100, with characteristics of resistance to Meloidogyne paranaensis; 4 biological nematicides, and 2 additional controls.

The active ingredients and their relative dosages of product employed in the experiment, and the arrangement of the applied treatments, are shown in Tables 1 and 2, respectively.

The assay was assembled on three unified workbenches measuring 3.0 meters in length by 1.0 meter in width and 1.0 meter in height from the ground to avoid soil contamination. Plastic PVC pots with capacity for five liters of autoclaved substrate containing $50 \%$ of soil composition and $50 \%$ of average sand were placed on the workbenches. Sand was added to the soil in order to create a better habitat for the nematode. The coffee seeds were sown in plastic bags in May 2017 containing two seeds per substrate and, after 50 days, thinning was performed, leaving only one plant per substrate. After 180 days, the seedlings were transplanted into the pots in the greenhouse.

On the same day of the transplanting of the seedlings were made the inoculations, the volume used was 3,780 eggs and / or J2 of M. exigua per plant, a compound suspension of $7 \mathrm{~mL}$ per plant.

The inoculum was obtained from a coffee area of 18 years, in the municipality of AraguariMG. The roots containing galls were collected and separated into two samples, one of them sent to the Laboratório de Recursos Genéticos e Biotecnologia da Embrapa, em Brasília-DF, to identify the J2 DNA was extracted according to the techniques described by Blacke et al. (1992) and Fallas et al. (1996), while the other went to the Instituto Federal Goiano - Campus Urutaí, to be used as an inoculum

Egg extraction was performed by means of trituration, in a blender, with the coffee roots in $0.5 \%$ sodium hypochlorite solution. Then, through centrifugation in sucrose solution, the eggs and juveniles were obtained in water, free of root fragments and other impurities (BONETTI; FERRAZ, 1981). After 30 days of transplanting and inoculation, the treatments were applied to the plants via a volumetric pipette to simulate drench application used in the field, with broth volumes of 500 liters per ha ${ }^{-1}$. 
TABLE 1 - Treatments used in the experiment and respective doses.

\begin{tabular}{|c|c|c|c|}
\hline \multicolumn{2}{|l|}{ Treatments } & Nematicides & Doses (P.C. ha ${ }^{-1}$ ) \\
\hline & Cultivate & & \\
\hline 1 & IPR 100 & Control & - \\
\hline 2 & IPR 100 & $\begin{array}{c}\text { Bacillus subtilis }+ \text { Bacillus methylotrophicus }+ \\
\text { Trichoderma asperellum }\end{array}$ & $\begin{array}{c}250 \mathrm{~mL}+250 \mathrm{~mL}+ \\
150 \mathrm{~g}\end{array}$ \\
\hline 3 & IPR 100 & Bacillus subtilis & $250 \mathrm{~mL}$ \\
\hline 4 & IPR 100 & Trichoderma asperellum & $150 \mathrm{~g}$ \\
\hline 5 & IPR 100 & Bacillus methylotrophicus & $250 \mathrm{~mL}$ \\
\hline 6 & $\begin{array}{l}\text { Mundo Novo } \\
376-4\end{array}$ & Control & - \\
\hline 7 & $\begin{array}{l}\text { Mundo Novo } \\
376-4\end{array}$ & $\begin{array}{c}\text { Bacillus subtilis }+ \text { Bacillus methylotrophicus }+ \\
\text { Trichoderma asperellum }\end{array}$ & $\begin{array}{c}50 \mathrm{~mL}+250 \mathrm{~mL} \\
\mathrm{~g}\end{array}$ \\
\hline 8 & $\begin{array}{l}\text { Mundo Novo } \\
\text { 376-4 }\end{array}$ & Bacillus subtilis & $250 \mathrm{~mL}$ \\
\hline 9 & $\begin{array}{l}\text { Mundo Novo } \\
376-4\end{array}$ & Trichoderma asperellum & $150 \mathrm{~g}$ \\
\hline 10 & $\begin{array}{l}\text { Mundo Novo } \\
376-4\end{array}$ & Bacillus methylotrophicus & $250 \mathrm{~mL}$ \\
\hline
\end{tabular}

During the experiment, foliar insecticide application was conducted for the control of Leucopetera cooffella. The insecticide consisted of Curyom ${ }^{\circledR} 550$ EC (Profenofos + Lefunuron), at a dose of $500 \mathrm{~mL} \mathrm{ha}^{-1}$ and a flow of $300 \mathrm{~L} \mathrm{ha}^{-1}$.

The following variables were evaluated: plant height, stem diameter, number of leaf pairs, and chlorophyll index at 30,60, 90, 120, and 150 days after inoculation (DAI). A ruler, pachymeter, and chlorophyll meter (IDClorofila) were employed for such assessments, respectively.

At the end of $150 \mathrm{DAI}$, the nematological evaluations were carried out, where each pot constituted a sample for analysis. Soil and roots were collected, in which each pot consisted of a sample for soil analysis, and the total root volume of the plants for the root analyses. After collection, the samples were taken directly to the Laboratório de Nematologia Agrícola do Instituto Federal de Goiano - Campus Urutaí for extraction and quantification.

In the laboratory, the roots were stained with Floxin B (TIHOHOD, 1993) to evaluate the Gall Index (GI) and Egg Mass Index (EMI). After staining, the analysis was performed using the scale proposed by Hartman and Sasser (1895), followed by extractions of Meloidogyne exigua using the Coolen and D'herde method (1972) for root extraction. Next, for the soil extraction, the methodology of centrifugation flotation in sucrose solution was employed, as proposed by Jenkins, (1964).

The population of M. exigua was quantified by observation under a stereoscopic microscope. The analyzed variables comprised the total number of $M$. exigua in the soil and roots; and the reproductive factor was calculated, $\mathrm{RF}=\mathrm{Fp} / \mathrm{Ip}$ (RF: Reproductive Factor; Fp: Final population; Ip: Initial population). If the RF is greater than 1 , the cultivar is considered susceptible, and if it is less than or equal to 1 , the cultivar is deemed resistant. (OOSTENBRINK, 1966)

The data were submitted to ANOVA in a time-repeated measures factorial scheme $(2 \times 4+2)$ for the variables plant height, stem diameter, leaf pairs and chlorophyll content, soil and root reproductive factor, egg mass, and gall index. The residual normality and homoscedasticity of the data were tested by the Shapiro-Wilk and Bartlett tests, respectively, the latter of which is considered sensitive regarding the normality hypothesis.

The Scott-Knott test was applied for multiple comparisons between means at 5\% significance. The soil and root reproductive factors (SRF and $\mathrm{RRF}$ ), egg mass (EM) and gall index (GI), plant height $(\mathrm{PH})$, stem diameter (SD), number of leaf 
pairs (NLP), and chlorophyll content (CC) were submitted to multivariate analysis (MANOVA), after apparent differences between the treatments studied by Biplot analysis for canonical variables with $95 \%$ confidence ellipses. All statistical analyses were performed using the $\mathrm{R}$ program $(\mathrm{R}$ Core Team, 2018).

At the end of the 150 days after inoculation, nematological analyses were conducted regarding the following variables: soil reproductive factor (SRF), root reproductive factor (RRF), gall index (GI), and egg mass index (EMI).

\section{RESULTS AND DISCUSSION}

Significant differences $(\mathrm{p}<0.05)$ were found, as verified in Figure 1, where T1 (IPR100 - Control), T2 (IPR-100 - B. subtilis + B.methylotrophicus + T. asperellum), T3 (IPR-100 - Bacillus subtilis), T4 (IPR-100 Trichoderma asperellum), T5 (IPR-100 - Bacillus methylotrophicus), and T7 (Mundo Novo - B. subtilis $+B$. methylotrophicus + T.asperellum) were statistically similar. In other words, treatment 7 (Mundo Novo - B. subtilis + B. methylotrophicus + T.asperellum), which consisted of a mixture of biological nematicides, was significantly equal to the treatments that contained the IPR-100 cultivar.

The genus Bacillus has shown great aptitude for the control of phytonematoids, presenting different modes of action (MACHADO et al., 2016), already in the genus Trichoderma the observed results must the production of mycotoxins and more 100 metabolites with antibiotic activity including polyketides, pironas, terpenes, metabolites derived from amino acids and polypeptides (SIVASITHAMPARAM; GHISALBERTI 1998).

Treatment T6 (Mundo Novo - Control), T8 (Mundo Novo - Bacillus subtilis), T9 (Mundo Novo - Trichoderma asperellum), and T10 (Mundo Novo - Bacillus methylotrophicus) also presented statistical equality but were highlighted as the worst treatments for the control of M. exigua.

Nonetheless, the root reproductive factor and the gall index were higher in treatments T6 (Mundo Novo - Control) and T10 (Mundo Novo - Bacillus methylotrophicus), while the soil reproductive factor was more abundant in T8 (Mundo Novo - Bacillus subtilis) and T9 (Mundo Novo - Trichoderma asperellum). The egg mass, in turn, showed to be median between T6 (Mundo Novo - Control), T7 (Mundo Novo - B. subtilis + B. methylotrophicus + T.asperellum), T10
(Mundo Novo - Bacillus methylotrophicus), T8 (Mundo Novo - Bacillus subtilis), and T9 (Mundo Novo - Trichoderma asperellum), where a strong positive correlation between the variables root reproductive factor and gall index was observed, i.e., both increase simultaneously.

The results observed with expression of the mixture of biological control agents has shown that they have great reproach characteristics such as the genus Trichoderma which is characterized by rapid growth and by producing numerous conidia, facilitating their colonization in the rhizosphere of plants. Due to their wide range of activities, they are characterized by parasitizing eggs and juveniles through the production of enzymes (HOWELL, 2003). Borges et al. (2013) observed that there was a decrease in the number of eggs and juveniles of Meloidogyne incognita in the bean soil, in addition to the reduction of the number of galls. Ferreira et al. (2008) and Sharon et al. (2001) concluded that some species of this genus parasitized eggs of $M$. exigua and $M$. javanica.

For bacteria of the genus Bacillus, the control result has already been observed by Lanna Filho et al. (2010) who showed that the use of $B$. subtilis was effective in the reduction of diseases in the field. Araújo and Marchesi (2009) concluded that the control of juveniles and egg mass in the tomato root excelled when using Bacillus compared to other treatments. In the mixture with other biological organisms, there is no competition for having different mechanisms of action, and all the conditions for the development of the same were favorable in the soil in question.

The mechanism of action of $B$. subtilis on the nematode still needs to be better evaluate, however, the effect of the bacteria on root exudates and the consequent disorientation of the nematode should be considered (ARAÚJO et al., 2012). With the nematode disoriented in the soil, this becomes an easy target for predation by other fungi such as the genus Trichoderma. Sharma and Gomes (1996) reported that $B$. subtilis produced endotoxins that interfered in the reproductive cycle of nematodes, especially in juvenile oviposition and hatching.

In an experiment conducted by Mata et al. (2000), the authors identified a coffee genotype of the Catucaí cultivar (IAPAR Vit. 83) that gave rise to the IPR-100 cultivar, which ensured $100 \%$ resistance to Meloidogyne paranaensis. The authors characterized the genotype as retaining good production and normal vegetative vigor, while the other cultivars analyzed in the same experiment did not develop well, having displayed considerably low values for the two variables, accounting for several plant deaths. 


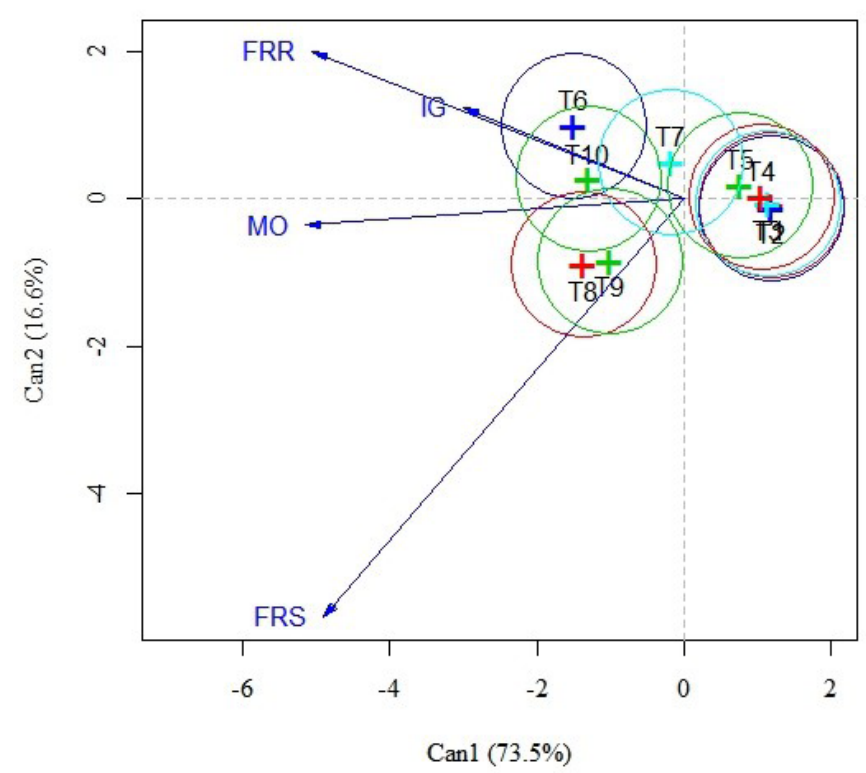

FIGURE 1 - Biplot of average scores of 4 variable canoes under the effect of 10 treatments with $95 \%$ confidence. FRR; Playback factor in the root. FRS; Non-solo reproduction factor, MO; Index of egg mass, IG; Galls index. T1; Treatment 1 (IPR100 - Witness), T2, Treatment 2 (IPR-100 - B. subtilis + B.methylotrophicus + T. asperellum), T3; Treatment 3 (IPR100 - B. subtilis), T4; Treatment 4 (IPR100 - T. asperellum), T5; Treatment 5 (IPR100 - B. methylotrophicus), T6; Treatment 6 (IAPAR Mundo Novo 3764 - Witness), T7, Treatment 7 (IAPAR Mundo Novo 3764 - B. subtilis + B.methylotrophicus + T. asperellum), T8; Treatment 8 (IAPAR Mundo Novo 3764 - B. subitilis), T9; Treatment 9 (IAPAR Mundo Novo 3764 - T. asperellum), T10; Treatment 10 (IAPAR Mundo Novo 3764 - B. methylotrophicus).

As for the vegetative observations made throughout the evaluations of plant height, stem diameter, number of leaf pairs, and chlorophyll index in the first evaluation at 30 days (Figure 2), they denote that there was a significant difference, but with practically all ellipses intersecting, i.e., the statistical differences were small within 30 days. However, the treatments of the cultivar IAPAR Mundo Novo 376-4 diverged from those of the IPR100 cultivar, the former of which were significantly greater regarding plant height and chlorophyll content.

Nonetheless, treatment 5 (IPR100 Bacillus methylotrophicus), within the IPR100 group, was the most efficient concerning stem diameter, thus generating a vegetative increase. Treatment 1 (IPR100 - Control) was the least effective regarding the vegetative evaluations.

In the second evaluation period at 60 days (Figure 3), the statistical differences increased. It can be noted that treatment 10 (Mundo Novo - Bacillus methylotrophicus) obtained the most significant plant height and stem diameter, followed by the other treatments containing the Mundo Novo cultivar. A second group (including cultivar IPR100) stood out as presenting the worst vegetative yields, which accounted for the characteristics of lesser plant development. However, such an outcome was not influenced by the applied biological treatments, but by the characteristics of the genotype.

Within the IPR100 cultivars, treatment 1 (IPR100 - Control) was considered as obtaining the lowest yield regarding the evaluated characteristics, suggesting that the biological control agents generated a vegetative increase.

Bburkett-cadena et al. (2008) had already evaluated the effects of Bacillus spp. regarding the influence on plant growth, and verified that the plants of the Mundo Novo cultivar underwent a more severe attack of the analyzed nematode. This effect of higher growth in height, in the treatment 10, was due to the presence of the genus Bacillus because of the reason that this bacterium increases nitrogen fixation, nutrient solubilization, phytorium synthesis and soil improvement. 


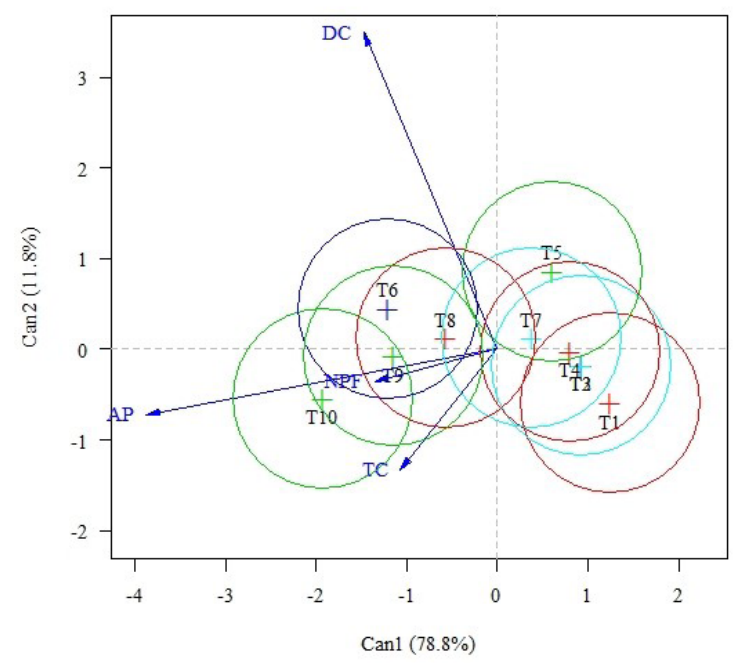

FIGURE 2 - Biplot analysis of the mean scores of four variables under the effect of ten treatments, at 30 days, with ellipses of $95 \%$ confidence. NPF; Number of pairs of leaves. AP; Plant height, DC; Diameter of stem, TC; chlorophyll content. T1; Treatment 1 (IPR100 - Witness), T2, Treatment 2 (IPR-100 - B. subtilis + B.methylotrophicus $+T$. asperellum), T3; Treatment 3 (IPR100 - B. subtilis), T4; Treatment 4 (IPR100 - T. asperellum), T5; Treatment 5 (IPR100 - B. methylotrophicus), T6; Treatment 6 (IAPAR Mundo Novo 3764 - Witness), T7, Treatment 7 (IAPAR Mundo Novo 3764 - B. subtilis + B.methylotrophicus + T. asperellum), T8; Treatment 8 (IAPAR Mundo Novo 3764 - B. subitilis), T9; Treatment 9 (IAPAR Mundo Novo 3764 - T. asperellum), T10; Treatment 10 (IAPAR Mundo Novo 3764 - B. methylotrophicus).

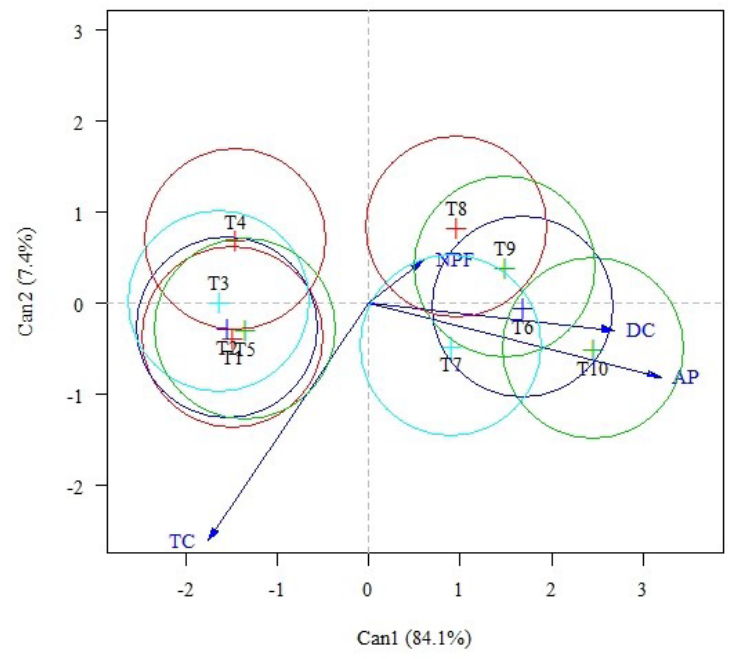

FIGURE 3 - Biplot analysis of the mean scores of four variables under the effect of ten treatments, at 60 days, with ellipses of $95 \%$ confidence. NPF; Number of pairs of leaves. AP; Plant height, DC; Diameter of stem, TC; chlorophyll content. T1; Treatment 1 (IPR100 - Witness), T2, Treatment 2 (IPR-100 - B. subtilis + B.methylotrophicus $+T$. asperellum), T3; Treatment 3 (IPR100 - B. subtilis), T4; Treatment 4 (IPR100 - T. asperellum), T5; Treatment 5 (IPR100 - B. methylotrophicus), T6; Treatment 6 (IAPAR Mundo Novo 3764 - Witness), T7, Treatment 7 (IAPAR Mundo Novo 3764 - B. subtilis + B.methylotrophicus + T. asperellum), T8; Treatment 8 (IAPAR Mundo Novo 3764 - B. subitilis), T9; Treatment 9 (IAPAR Mundo Novo 3764 - T. asperellum), T10; Treatment 10 (IAPAR Mundo Novo 3764 - B. methylotrophicus). 
In the third evaluation of the vegetative characteristics at 90 days (Figure 4), the two groups of cultivars were well defined, where those of cultivar IPR100 showed significant differences regarding the Mundo Novo cultivar. However, among the treatments of the same crop of IPR100 that were all statistically the same, retaining the lowest values, the result of chlorophyll content was highlighted, in which the treatments using the IPR 100 cultivar presented considerably higher values.

In turn, in the treatments of the second group of the cultivar Mundo Novo, treatment 10 (Mundo Novo - Bacillus methylotrophicus) was again distinguished, with the best result considering plant height and stem diameter, although it was statistically similar to the other treatments. Treatment 7 (Mundo Novo - Bacillus subtilis + Bacillus methylotrophicus + Trichoderma asperellum), which comprised a mixture of biological nematicides, also stood out, having obtained the most expressive result for the number of leaf pairs, plant height, and stem diameter. The results suggest that the biological control agent incremented vegetative growth.

At 90 days the TC (chlorophyll content) is opposite to the others (NPF, DC, AP) due to the application to the control of Leucoptera cooffella. The insecticide consisted of Curyom ${ }^{\circledR} 550$ EC (Profenofos + Lefunuron) at a dose of $500 \mathrm{~mL}$ ha-1 and a flow rate of $300 \mathrm{~L}$ ha- 1 .
In the 120 DAI evaluation (Figure 5), the stabilization of plant growth began, in which 2 groups were again observed (IPR100 and Mundo Novo, respectively). The only significant difference was found between the two groups of cultivars. Among the treatments within each cultivar, both were statistically the same. The treatments containing the Mundo Novo cultivars were superior in plant height and stem diameter, although inferior regarding the number of leaf pairs and chlorophyll content when compared with the IPR100 cultivar. In other words, the biological control agents no longer influenced plant development, a result that was also observed during the evaluation at 150 DAI (Figure 6).

According to the results regarding the morphological assessments, the differences observed above were due to the mechanism of action of the biological control agents, which can be by competition, antibiosis, and parasitism (DEMIRCI et al., 2011). Microorganisms can stimulate plant growth directly through the production of hormones, biological nitrogen fixation, phosphorus solubilization, acceleration of the mineralization process, and siderophore production, and indirectly through the induction of systemic resistance, production of antibiotics, and antagonism towards pathogens (DALLEMOLEGIARETTA et al., 2015).

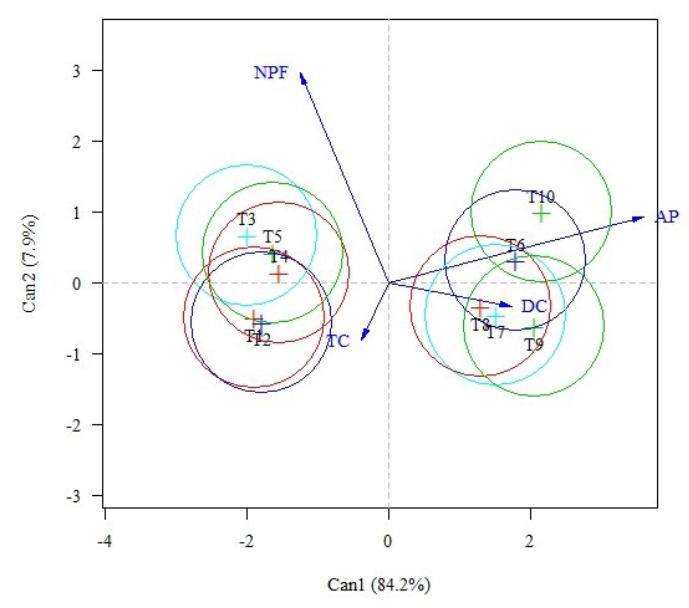

FIGURE 4 - Biplot analysis of the mean scores of four variables under the effect of ten treatments, at 90 days, with ellipses of $95 \%$ confidence. NPF; Number of pairs of leaves. AP; Plant height, DC; Diameter of stem, TC; chlorophyll content. T1; Treatment 1 (IPR100 - Witness), T2, Treatment 2 (IPR-100 - B. subtilis + B.methylotrophicus + T. asperellum), T3; Treatment 3 (IPR100 - B. subtilis), T4; Treatment 4 (IPR100 - T. asperellum), T5; Treatment 5 (IPR100 - B. methylotrophicus), T6; Treatment 6 (IAPAR Mundo Novo 3764 - Witness), T7, Treatment 7 (IAPAR Mundo Novo 3764 - B. subtilis + B.methylotrophicus + T. asperellum), T8; Treatment 8 (IAPAR Mundo Novo 3764 - B. subitilis), T9; Treatment 9 (IAPAR Mundo Novo 3764 - T. asperellum), T10; Treatment 10 (IAPAR Mundo Novo 3764 - B. methylotrophicus). 


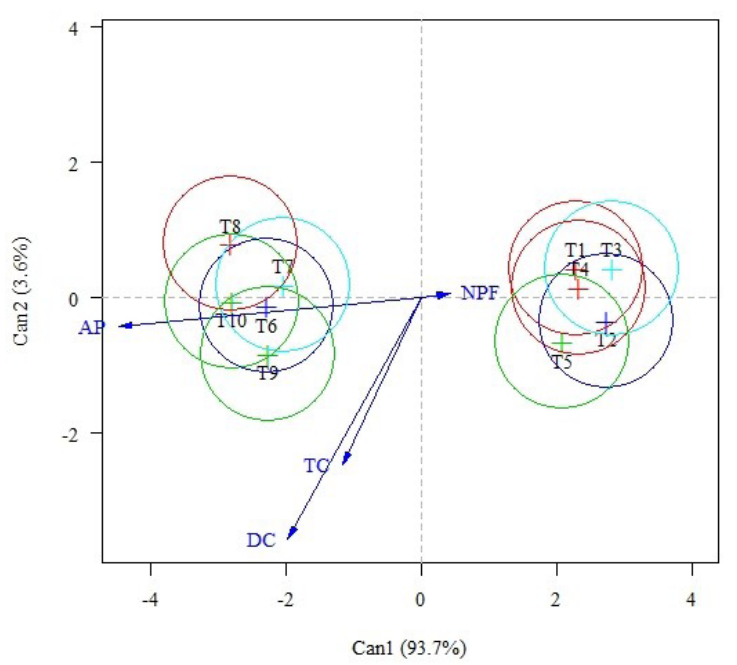

FIGURE 5 - Biplot analysis of the mean scores of four variables under the effect of ten treatments, at 120 days, with ellipses of $95 \%$ confidence. NPF; Number of pairs of leaves. AP; Plant height, DC; Diameter of stem, TC; chlorophyll content. T1; Treatment 1 (IPR100 - Witness), T2, Treatment 2 (IPR-100 - B. subtilis + B.methylotrophicus $+T$. asperellum), T3; Treatment 3 (IPR100 - B. subtilis), T4; Treatment 4 (IPR100 - T. asperellum), T5; Treatment 5 (IPR100 - B. methylotrophicus), T6; Treatment 6 (IAPAR Mundo Novo 3764 - Witness), T7, Treatment 7 (IAPAR Mundo Novo 3764 - B. subtilis + B.methylotrophicus + T. asperellum), T8; Treatment 8 (IAPAR Mundo Novo 3764 - B. subitilis), T9; Treatment 9 (IAPAR Mundo Novo 3764 - T. asperellum), T10; Treatment 10 (IAPAR Mundo Novo 3764 - B. methylotrophicus).

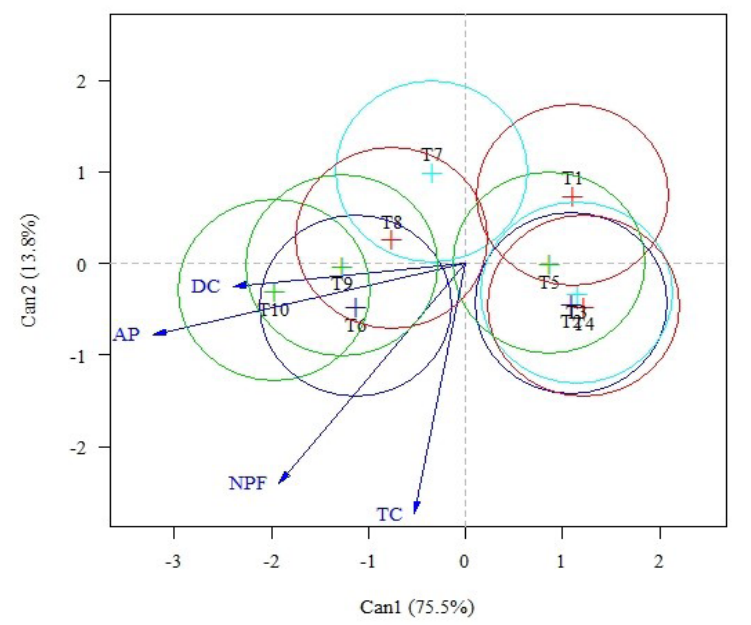

FIGURE 6 - Biplot analysis of the mean scores of four variables under the effect of ten treatments, at 150 days, with ellipses of $95 \%$ confidence. NPF; Number of pairs of leaves. AP; Plant height, DC; Diameter of stem, TC; chlorophyll content. T1; Treatment 1 (IPR100 - Witness), T2, Treatment 2 (IPR-100 - B. subtilis + B.methylotrophicus $+T$. asperellum), T3; Treatment 3 (IPR100 - B. subtilis), T4; Treatment 4 (IPR100 - T. asperellum), T5; Treatment 5 (IPR100 - B. methylotrophicus), T6; Treatment 6 (IAPAR Mundo Novo 3764 - Witness), T7, Treatment 7 (IAPAR Mundo Novo 3764 - B. subtilis + B.methylotrophicus + T. asperellum), T8; Treatment 8 (IAPAR Mundo Novo 3764 - B. subitilis), T9; Treatment 9 (IAPAR Mundo Novo 3764 - T. asperellum), T10; Treatment 10 (IAPAR Mundo Novo 3764 - B. methylotrophicus). 


\section{CONCLUSIONS}

The effect of genetic resistance was superior to the effect of biological nematicides. For the management of Meloidogyne exigua with the susceptible cultivar (IAPAR Mundo Novo 376-4), it is recommended to use the nematicide mixture (Bacillus subtilis + Bacillus methylotrophicus + Trichoderma asperellum), aiming to equate the management with the cultivar resistant (IPR100).

The association with the control by Bacillus methylotrophicus promotes vegetative growth within the IAPAR Mundo Novo cultivar 376-4 more clearly up to 90 days after inoculation

\section{REFERENCES}

ARAÚJO, F. F.; BRAGANTE, R. J.; BRAGANTE, C. E. Controle genético, químico e biológico de meloidoginose na cultura da soja. Pesquisa Agropecuária Tropical, Goiânia, v. 42, n. 2, p. 220224, 2012.

ARAÚJO, F.F de. Bacillus subtilis: Biocontrolador de fitonematóides. 2015. Available from: <http://www. revistacampoenegocios.com/>. Accessed on: May 28, 2018.

ARAÚJO. F. F.; MARCHESI, G. V. P. Uso de Bacillus subtilis no controle da meloidoginose e na promoção do crescimento do tomateiro. Ciência Rural, Santa Maria, v.39, n.5, p.1558-1561, 2009.

BHATTACHARYYA, P.N.; JHA, D.K. Plant GrowthPromoting Rhizobacteria (PGPR): Emergence in Agriculture. World Journal of Microbiology and Biotechnology, 28, 1327-1350, 2012.

BLACKE, M. C. et al. Use of random amplified polymorphic DNA polymerase chain reaction (RAPDPCR) to detect DNA polymorphisms in aphids (Homóptera:Aphididae). Bulletin of Entomological Research, v. 82, p. 151- 159, 1992.

BONETTI, J.I.S.; FERRAZ, S. Modificação do método de Hussey e Barker para extração de ovos de Meloidogyne exigua de cafeeiro. Fitopatologia Brasileira, Brasília, v.6, n.3, p.553, 1981.

BORGES, F. G. et al. Manejo alternativo de nematoides de galha (Meloidogyne incognita) em feijoeiro (Phaseolus vulgaris). Scientia Agraria Paranaensis, Mal. Cdo. Rondon, v. 12, suplemento, p. 425-433, 2013.
BURKETT-CADENA et al. Suppressiveness of rootknot nematodes mediated by rhizobacteria. Biological Control, Amesterdam, v.47,p. 55-59, 2008.

CARDOSO, R.B.; ARAÚJO, F.F. Multiplicação de Bacillus subtilis em vinhaça e viabilidade no controle da meloidoginose, em cana-de-açúcar. Revista Brasileira de Engenharia Agrícola e Ambiental, Campina Grande, v.15, p.1283-1288, 2011

COMPANHIA NACIONAL DE ABASTECIMENTO. Acompanhamento da safra brasileira de café, Safra 2018: quarto levantamento. Brasília, 2018. Available from: $<$ https://www.conab.gov.br/>. Accessed on: May $28,2018$.

COOLEN, W. A.; D'HERDE, C. J. A method for the quantitative extration of nematodes from plant tissue. State Agriculture Research Center - GHENT, Belgium. p.77. 1972.

DALLEMOLE-GIARETTA et al. Pochonia chlamydosporia promotes the growth of tomato and lettuce plants. Acta Scientiarum Agronomy, Maringá v.37, p.417-423, 2015.

DEMIRCI, E.; DANE, E.; EKEN, C. In vitro antagonistic activity of fungi isolated from sclerotia on potato tubers against Rhizoctonia solani. Turkish Journal of Biology, Ankara, v.35, p.457-462, 2011.

FALLAS, G. A. et al. Molecular and biochemical diversity among isolates of Radopholus spp. From different areas of the world. Journal of Nematology, v. 28, p. 422-430, 1996.

FERREIRA, L. T.; EMBRAPA. Cafés do Brasil são exportados para 99 países e geram receita cambial de US\$ 808 milhões no primeiro bimestre de 2018. 2018. Available from: $<$ https://www.embrapa.br/buscade-noticias/-/noticia/32735306/cafes-do-brasil-saoexportados-para-99-paises-e-geram-receita-cambialde-us-808-milhoes-no-primeiro-bimestre-de-2018> . Accessed on: Oct. 01, 2018.

FERREIRA, P.A. et al. Parasitismo de ovos de Meloidogyne exigua por fungos nematófagos e estudo de compatibilidade entre isolados fúngicos. Revista Trópica - Ciências Agrárias e Biológicas, Viçosa, v.2, n.3, p.15, 2008.

GONÇALVES, W. et al. Manejo de nematóides na cultura do cafeeiro. In: REUNIÃOO ITINIRANTE DE FITOSSANIDADE DO INSTITUTO BIOLÓGICOCAFÉ, 10, 2004, Mococa. Anais... São Paulo: Instituto Biológico, p. 48-66, 2004. 
HOWELL, C. R. Mechanisms employed by Trichoderma species in the biological control of plant diseases: the history and evolution of current concepts. Plant Disease, St. Paul, v. 87, n. 1, p. 4-10, 2003.

JENKINS W.R. A rapid centifugal-flotation technique for separating nematodes from soil. Plant Disease Reporter, v.48 p.692, 1964

LANNA FILHO, R.; FERRO, H. M.; PINHO, R. S. Controle biológico mediado por Bacillus subtilis. Revista Trópica - Ciências Agrárias e Biológicas. v. 4, n. 2, p. 12, 2010.

LINFORD, M. B.; YAP, F.; OLIVEIRA, J. M. Reduction of soil populations of root-knot nematode during decomposition of organic matter. Soil Science, New Brunswick, p. 127-141, 1938.

MACHADO; et al. Biological control. In: Galbieri R.; BELOT R. J. ed. Phytopharasites nematodes of cotton in Brazilian Cerrados and control measures. Cuiabá, MT, Instituto Mato Grosso do Algodão. Cuiabá, MT, Instituto Mato-grossense do Algodão, p. 287-312, 2016.

MATA, J. S. da; et al. Seleção para resistência ao nematóide Meloidogyne paranaensis EMN-95001: IAPARLN 94066 de "Catuaí x Icatu" em área altamente infestada. In: SIMPÓSIO DE PESQUISA DOS CAFÉS DO BRASIL, 1, 2000, Poços de Caldas. Resumos expandidos. Brasília: EMBRAPA, p. 515 - 518, 2000.

OLIVEIRA, D.S. et al. Characterization of Meloidogyne incognita populations from São Paulo and Minas Gerais state and their pathogenicity on coffee plants. Tropical Plant Pathology, Viçosa, v.36, n.3, p.190-194, 2011.
OOSTENBRINK, M. Major characteristics of the relation between nematodes and plants. Wageningen: Plantenziektenkundige dienst, v.66, p.1-46, 1966.

$\mathrm{R}$ Core Team. R: A language and environment for statistical computing. $R$ Foundation for Statistical Computing. Vienna, Austria. http:/www.R-project. org/. Accessed on: Sept. 27, 2018.

SHARMA, R. D.; GOMES, A. C. Effect of Bacillus spp. toxins on oviposition and juvenile hatching of Heterodera glycines. Nematologia Brasileira, Brasília, v.20, n. 1, p.53- 62, 1996.

SHARON, E. et al. Biological control of the rootknot nematode Meloidogyne javanica by Trichoderma harzianum. Phytopathology, v.91, p.687-693, 2001.

SIVASITHAMPARAM K. AND GHISALBERTI E. Secondary metabolism in Trichoderma and Gliocladium. In: HARMAN GE, KUBICEK CP, editors. Trichoderma and Gliocladium. London: Taylor and Francis. p. 139-192, 1998.

STIRLING, G.R. Biological control of plant-parasitic nematodes. 2. ed, Sidney: p. 551, 2014

TIHOHOD, D. Nematologia agrícola aplicada. Jaboticabal: FUNEP/UNESP, p. 372, 1993.

ZHOU, L. et al. Evaluation of bacterial biological control agents for controlo of root-knot nematode disease on tomato. Crop Protection, United Kingdom, v.84, p.8-13, 2016. 